\title{
Design of a parklet for the handcraft artisians comunity development
}

\section{Diseño de un parklet para el desarrollo de comunidades artesanas}

\author{
BUCK-DURÁN, Enrique Isaac†, NIVÓN-PELLÓN, Alejandra* and GARCÍA-PITOL, Jorge
}

Universidad Autónoma de Querétaro,

ID $1^{\text {st }}$ Author: Enrique Isaac, Buck-Durán / ORC ID: 0000-0001-9800-5974, CVU CONACYT ID: 1034858

ID $1^{\text {st }}$ Co-author: Alejandra, Nivón-Pellón / ORC ID: 0000-0002-1715-4335, Researcher ID Thomson: V-8717-2018, CVU CONACYT ID: 668097

ID $2^{\text {nd }}$ Co-author: Jorge Arturo, García-Pitol / CVU CONACYT ID: 432511

\begin{abstract}
The artisan is a representative of Mexican culture, his techniques for making handicrafts passed down from generation to generation and their craftsmanship tells the story of his past. Over the years, they have become a vulnerable group, since their only livelihood is the creation of handicrafts, in many cases devalued. This project is focused on a specific artisan community that is concentrated in the Indigenous Craft Development Center (in its Spanish acronym, CEDAI) located in the city of Querétaro, Mexico whose intervention is pertinent since, despite being a fixed point of sale, the influx of this space is low, indicative of reduced sales. The objective of this work is the design of a parklet outside of the CEDAI making use of social methodologies to provoke a greater influx of people. Constructivism and phenomenology being the pillars of the project, and the Design thinking as the development guide which suggests the steps to carry out the product design. This work is an example of how the use of social methodologies in conjunction with design methodologies are the guide for the construction of urban elements that are sustainable.
\end{abstract}

Parklet, Constructivism, Phenomenology, Design thinking

\begin{abstract}
Resumen
El artesano es un representante de la cultura mexicana, sus técnicas de elaboración transmitidas de generación en generación y su artesanía cuenta la historia de su pasado. Con el paso de los años, se han convertido en un grupo vulnerable, ya que, su único medio de sustento es la creación de artesanía en muchos casos desvalorizada. Este proyecto, enfocado en una comunidad de artesanos concentrada en el Centro de Desarrollo Artesanal Indígena (CEDAI) ubicado en la ciudad de Querétaro, México, cuya intervención es pertinente ya que, a pesar de ser un punto de venta fijo, la afluencia de este espacio es baja, indicativo de ventas reducidas. El objetivo del presente trabajo es el diseño de un parklet (parque pequeño) al exterior del CEDAI haciendo uso de metodologías de índole social para provocar una mayor afluencia de personas. Siendo el constructivismo social y la fenomenología los pilares del proyecto, y el Design Thinking, la guía del desarrollo que sugiere los pasos para la realización del diseño del producto. Este trabajo es un ejemplo de cómo el uso de metodologías sociales en conjunto con metodologías de diseño son la guía para la construcción de elementos urbanos que sean sustentables y sostenibles.
\end{abstract}

Parklet, Costructivismo, Fenomenología, Design thinking

Citation: BUCK-DURÁN, Enrique Isaac, NIVÓN-PELLÓN, Alejandra and GARCÍA-PITOL, Jorge. Design of a parklet for the handcraft artisians comunity development. Journal of Social Researches. 2021. 7-20:29-37.

\footnotetext{
* Correspondence to Author (Email: alejandra.nivón@uaq.mx)

$\dagger$ Researcher contributing as first author.
} 


\section{Introduction}

From the development of the research and development of the project, a growing problem was registered in the city of Querétaro. The artisans of the region who are dedicated to selling their crafts, generally try to sell it near the downtown of the city and are classified as street vendors. This has become a big problem for them, because of the sale of handicrafts that represents the economic sustenance in the families of artisans.

There is a local proposal to address this problem from which the Indigenous Handicraft Development Center (by the acronym in spanish CEDAI) is created, where artisans have a decent space for the sale of their handicrafts, thus eliminating the problem of street vending; However, this solution gave rise to another problem, which is the low influx of people who visit and buy in this space.

It is intended that the installation of a parklet could solve the problem described above. Through strategic design it seeks to attract the attention of people who pass near the CEDAI, with the aim of allowing the crafts that are within this space to be exhibited, thus being an extension of CEDAI, thereby seeking to improve the influx of people and therefore the sale of handicrafts.

In this text will be shared the process of design of public space for urban intervention and the expected results for this project.

\section{Parklet and the artisans}

In 2010, according to the Ground Play web page (2020), small green spaces of $3.05 \times 6.09 \mathrm{~m}$ appear in neighborhoods in the city of San Francisco. These small parks, better known as parklets by the word park and let that that works as a diminutive, which replace parking spaces with a rest area that is open to all public. Each of them has an original design, some have simple designs, while others have more artistic approaches. An important characteristic is that they all comply with the American law for people with disabilities (ADA).
The City of San Francisco has taken an evidence-based approach to understanding the benefits of parklets. It includes a database of parklets in the city, this information is publicly available, and allows to know the impact that this type of urban intervention has in the areas where they have been placed.

The organization Ground Play (2020) gathers data together with interviews made directly to users, sponsors, passers-by, companies that are in the area and city personnel, this to observe the human impact that parklets have on people.

Mura (2013) describes the parklets project as the "most famous urban planning tactical change policy", as it exemplifies the entire cyclical process of formalizing an urban tactical intervention as a primary component for an environment of change within a city. In addition, it takes up the most important points of the great success of this project in the city of San Francisco, starting with the fact that the city demonstrated an important commitment to innovation in public spaces, on the other hand citizen activists inspired others and influenced them, the project itself received support from various leaders, which have had an impact on its institutionalization, on the other hand, the private sector found a win-win situation by contributing economically to this type of project. The Parklet project arrived in Mexico in 2013.

The destined place was the Federal District (now Mexico City or by its acronym in Spanish CDMX) with the name of "pocket park", this as a resolution to the problem of lack of recreational spaces in the city. The people in charge of bringing this project to Mexico were Tania Asaldi, Julien Salabelle and Gerardo Asaldi, members of the architectural firm "Development Architecture Sustainability" (DAS). The idea was developed from the creation of light structures that were easy and quick to assemble and disassemble, this with the aim of being able to move them to different spaces in the city. The approximate assembly time is 20 minutes with a work team of 3 people (Universidad de las Américas de Puebla, 2014). 
Another project was carried out by the Mexicaltzingo studio, which began in February 2017 and completed at the end of November of the same year with the authorization for its implementation. One of the obstacles that arose was that the neighbors were unaware of the benefits, which implied obtaining consent for the development of the project (Lepe, 2018).

The typical application of parklets is in narrow or very congested streets that prevent the installation of sidewalk cafes, or where tenants or residents of areas find the need to expand recreation areas to public space. Commonly, to obtain a parklet, tenants or property owners have to make an agreement with the city, in some places they do directly with a process already established by the city to request it, seeking to intervene one or more parking spaces. The parklets are normally managed by the society of some adjacent businesses or by residents of the area in order to keep them free of trash and dust. When there are no people to take care of this, the parklet must be installed and maintained by the city as a traditional park or public space (NACTO, 2015).

The advantages of praklets according to Jaller and his collaborators (2021) directly involve pedestrians, since there is an enormous advantage that the traffic that circulates includes the movement of pedestrians, thus helping urban traffic to serve more people. By promoting the implementation of more and better urban installations that facilitate pedestrian traffic, it generates a better transportation system. The parklet, being an urban facility that functions as a recreational space for pedestrians, helps to encourage pedestrian traffic and does not compromise the efficiency of the transport network, in addition, it is important to take into account that it gives life to the streets.

Based on the evidence of the benefits that parklets bring within the city, this project is relevant for solving the problem of the sale of handicrafts in CEDAI.

Speaking of artisans, Novelo (2002) points out that, for Western society, a craftsman is called that because of their way of working because they do not conform to the way of working and learning of the academy. Some of them produce creative, artistic and original objects, which are recognized by society, which also values the producer as a specialist in his job.
This can also include an entire family or even a community.

On the other hand, Martínez, et al, (2018) when referring to crafts comment that it is the set of activities carried out by an artisan that works with his hands. Few technological means are used for its creation, however, there are tools that facilitate the work. In ancient times, when modern machines and some of the tools that are used today did not exist, objects were made in a traditional way, for this reason craftsmanship was not considered an art. From a technological point of view, crafts can be defined as a production process that is fundamentally manual. For anthropologists, it is a traditional form of production, this being the tradition that inherits the techniques, tools and designs of the same crafts. On the other hand, from the cultural point of view, crafts are also considered as popular art, anonymous art that is transmitted from generation to generation, from parents to their children.

\section{Querétaro se Diseña}

Organization created by a group of experts from the creative sector, private initiative, civil society and the educational sector; its objective is to transform the city of Querétaro through design (Querétaro se Diseña, 2020).

In order to have a creative city, it is necessary to have a well-established collaborative network. This network is made up of the Council of Querétaro Creativo, the agency that managed to put the creative sectors at the forefront of the municipal public agenda. Its desire is to show the creative environment of the city, mainly, taking design as a trigger for social transformations in the country, Latin America and the world (Querétaro se Diseña, 2020).

The candidacy of the city of Santiago de Querétaro- Mexico, to be named "Creative City" was presented by the municipal government on July 15, 2019, with Frédéric Vacheeon Oriol, representative of UNESCO in Mexico. A part of this process consisted of the realization of a census that UNESCO conducted of more than 2,000 companies in the creative sector in the municipality of Querétaro (Márquez, 2019). 
Due to the above and for the purposes of the project, a collaboration was sought with the organization Querétaro se Diseña, with the aim of strengthening the support networks for the development of the parklet as an urban tactical intervention that results in a social and economic benefit for the artisan community. of CEDAI.

\section{Methodological framework}

The methodological approaches selected for the realization of this project were: constructivism and phenomenology, while Design thinking was a guide for the realization of the design, complemented in an overwhelming way with the Lego Serious Play methodology, implemented in the empathizing stage.

\section{Social construction}

For Carretero (2009), constructivism focuses on knowing the idea that individuals form with respect to social and cognitive aspects. Each individual generates these constructions with their daily experiences. Knowledge as such is not a reproduction equal to reality, but a construction that human beings, who live in society, make through perception. The individual develops this construction from the knowledge he has and his previous experiences, based on the environment and context in which it is developed.

\section{Phenomenology}

Phenomenology is characterized by focusing research on personal experience, as opposed to studying the facts from group perspectives. It is based on four key pillars: "temporality (lived time), spatiality (lived space), corporeality (lived body) and relationality or communality (lived human relationship)" (Álvarez-Gayou, 2003). Phenomenology considers that each human being has unique perceptions and experiences that are added to the experience and context of the individual with people, situations, objects and events.

J. Morse and L. Richards (2002) cited by Álvarez-Gayou (2002) say that phenomenology has two premises, the first is that personal perception gives evidence of the existence of the world, not as idealized in his head, but how you live it; thus, experiences and environment are fundamental elements in phenomenology.
The second premise tells us that the mere existence of the human is interesting and significant, since there is always consciousness, this implies that each individual can be described and understood in their own context (ÁlvarezGayou, 2002).

\section{Lego serious play}

This methodology according to González and Villamizar (2018) can be defined as a form of activity that is based on imagination, integrating social, cognitive and emotional dimensions with benefits of the same game to be influential in the challenges faced by organizations. The methodology is based on the Serious Game, which is the interaction between hands and brain and on analogical reasoning, that is, the use of knowledge from a "known domain to a less known one"; so it uses metaphors to make it easier for people to communicate when making decisions in organizations. In the methodology workshops, LEGO blocks are used so that the participants can build models with which they express ideas, around a theme or social construction, in an exploratory, synthetic and divergent way, for design purposes, these contributions are They are considered valuable in the first steps to formulate strategies.

\section{Design thinking}

Design thinking (DT) is a creative method to generate innovative ideas that focuses efforts on understanding and solving real user problems. This method is based on the thought processes of product designers (Design Thinking in Spanish, 2018), it began to be developed theoretically at Stanford University from the 70s, later the design consulting company IDEO develops it in depth, today it is its main ambassador.

The process that Design thinking follows considers 5 important steps to achieve innovation that can be seen in the following graphics: 


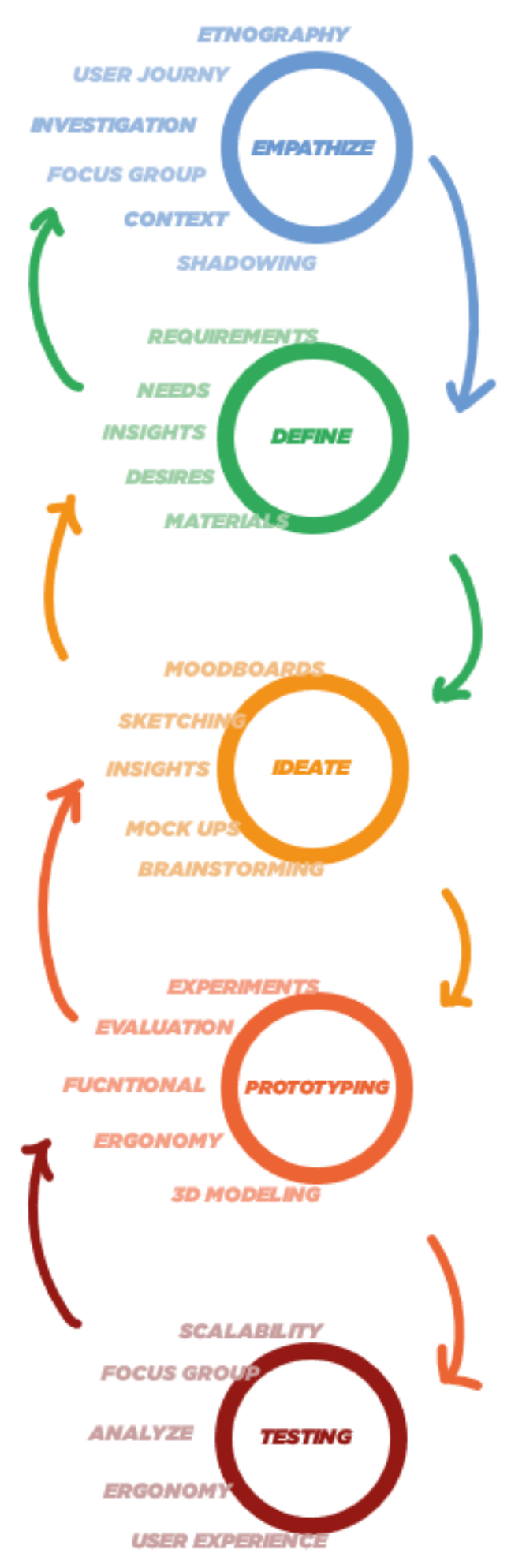

Graphic 1 Methodology for the development of the parklet design, based on the information from design thinking in Spanish (2018) and on Universal Methods of Design (2012)

\section{Methodologic implementation for the design}

Taking into account the use of the previously explained methodologies, a methodology was created that adjusted to the needs of the project and the result was the following:

\section{Empathize}

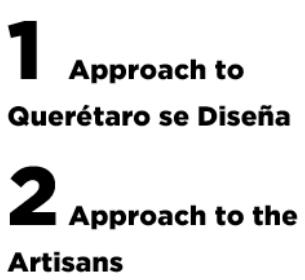

Artisans

\section{Define

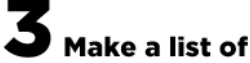 requirements

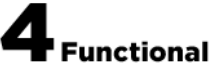 \\ structure}

Graphic 2 Methodology used for the design of the parklet based on the DT

Source: Own elaboration

\section{Approach to Querétaro se Diseña}

Agreements were made with the organization "Querétaro se Diseña" presenting the requirements of the project, the commitments for the production of the prototype, the agreements with the city and the corresponding permits to carry out this project were defined.

2. Approach to artisans

From a phenomenological social approach, based on Design thinking and the Lego Serious Play methodology, the design proposal for the development of a parklet was generated together with the artisans of CEDAI that would attract passersby and allow artisans to exhibit their products.

\section{Make a list of requirements}

The insights found in the previous stages were defined, this with the aim of making decisions regarding the needs of the artisans, the needs of the users and the needs of the place chosen for the implementation of the urban intervention. 


\section{Functional structure}

Along with the defined objectives and requirements, the functional structure of the product was realized, since through this step the functionality and user experience needed by both artisans and potential customers can be visualized.

\section{Generating design proposals}

In this step, the design proposals that meet the objectives, requirements and functions defined above are materialized.

\section{Focus grups for design validation}

A focus group with artisans was prepared to choose the design proposal that best suits their needs, in addition to a second focus group to learn the ideas of potential clients. At the end, a list of requirements is generated to improve the product.

\section{Final changes in the design proposal}

Potential improvements were visualized for the final proposal, which was presented to the artisans to finalize details. After completing the validation, the prototype production plans are made.

\section{Rapid prototyping}

Rapid prototypes were made for validation of the space; dimensions, ergonomics, functionality and user experience.

\section{Results}

\section{Empathize and define}

The application of the Lego Serious Play methodology achieved integration and approchement with the volunteer artisans at CEDAI. The interview with the artisans and a structured survey helped to detect symbolism that enrich the proposal to arrive at the best possible design. Table 1 shows the set of most frequent responses in the interviews carried out.

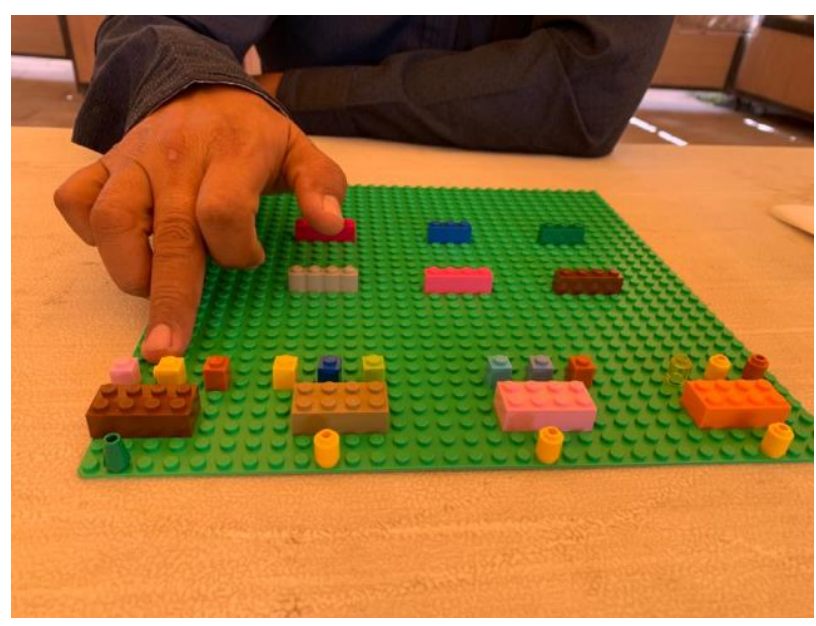

Graphic 3 Craftsman explaining his idea for the parklet through the Lego Serious Play methodology

\begin{tabular}{|l|l|r|}
\hline \multicolumn{2}{|c|}{ Question } & $\begin{array}{c}\text { \% of the } \\
\text { answers }\end{array}$ \\
\hline $\begin{array}{l}\text { Do you make crafts } \\
\text { or only sell them? }\end{array}$ & $\begin{array}{l}\text { I and sell } \\
\text { crafts }\end{array}$ & $86 \%$ \\
\hline $\begin{array}{l}\text { Are there more } \\
\text { members of the } \\
\text { family dedicated to } \\
\text { make crafts? }\end{array}$ & $\begin{array}{l}\text { Every member of } \\
\text { participates }\end{array}$ & $86 \%$ \\
\hline $\begin{array}{l}\text { How cam we } \\
\text { represent our culture } \\
\text { in a public space? }\end{array}$ & $\begin{array}{l}\text { It has to look } \\
\text { handcrafted }\end{array}$ & $57 \%$ \\
\hline $\begin{array}{l}\text { What color do you } \\
\text { think reflects more } \\
\text { the Mexican culture? }\end{array}$ & Vivid and flashy & $71 \%$ \\
\hline $\begin{array}{l}\text { What type of } \\
\text { furniture would you } \\
\text { put up for crafts } \\
\text { exhibit? }\end{array}$ & exhibitors & $71 \%$ \\
\hline $\begin{array}{l}\text { What kind of crafts } \\
\text { would you exhibit? }\end{array}$ & $\begin{array}{l}\text { Every craft that is } \\
\text { in the CEDAI }\end{array}$ & $100 \%$ \\
\hline $\begin{array}{l}\text { Would you give } \\
\text { courses in a public } \\
\text { space of this size? }\end{array}$ & Yes & $85 \%$ \\
\hline
\end{tabular}

Table 1 Responses highlighted in the survey of CEDAI artisans in the LSP methodology

\section{Ideation}

In this stage, the requirements established from the interviews with the artisans and the evaluation of the needs were taken into account. The first step was the realization of sketches from these ideas for the realization of the product, later singular elements were taken and adhered to the requirements and needs of the project, exploring different forms and spaces for a functional parklet design. 


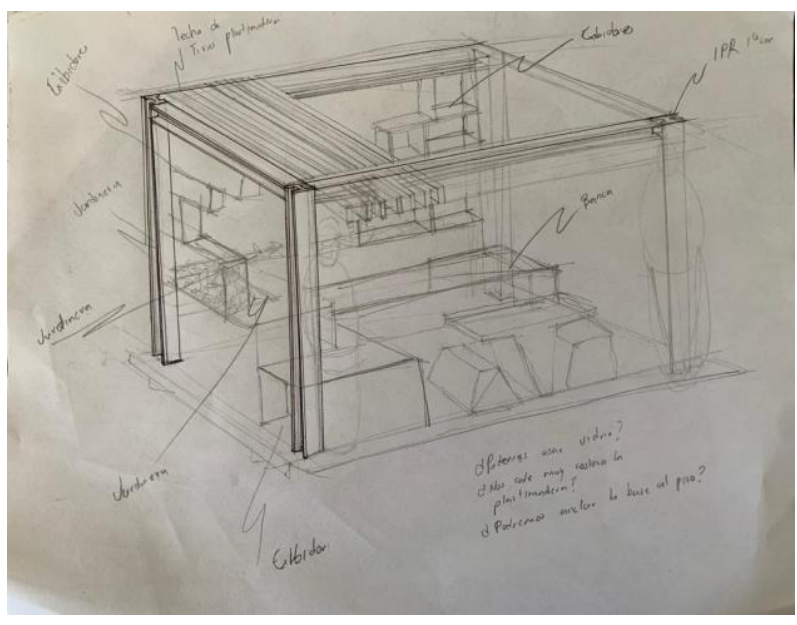

Graphic 4 Sketch, according to the requirements established for the parklet

In the next step of the ideation, a dynamic was carried out that allows the spatial interaction of the elements. With tapes on the ground and chairs, spaces were identified for the construction of the parklet, taking into account the elements that were required in the project and their needs. The best arrangement for its design was defined through this exercise. 4 displays were made in a space of $5 \times 2.2 \mathrm{~m}$.

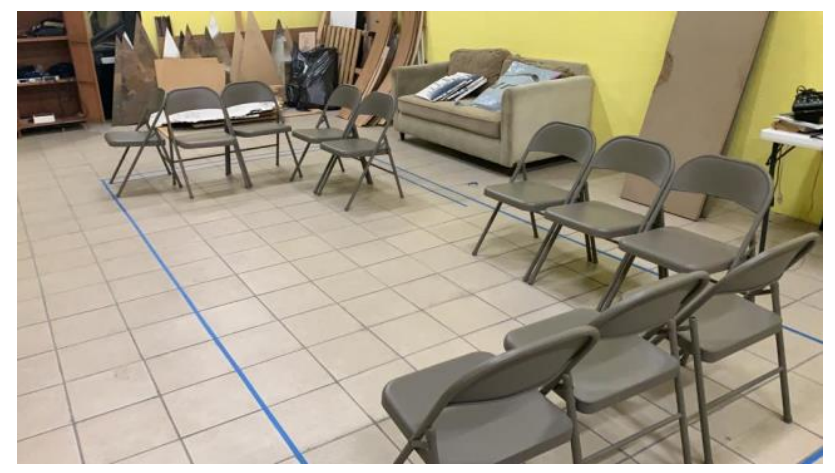

Graphic 5 Selected display in the dynamics of spatial interaction

Having already defined the elements of the project and the design idea for the realization of the product, the proposal was worked on with the help of CAD software (Computer Aded Design) SolidWorks 2020, to establish a clear idea of what it is intended to achieve with the product.

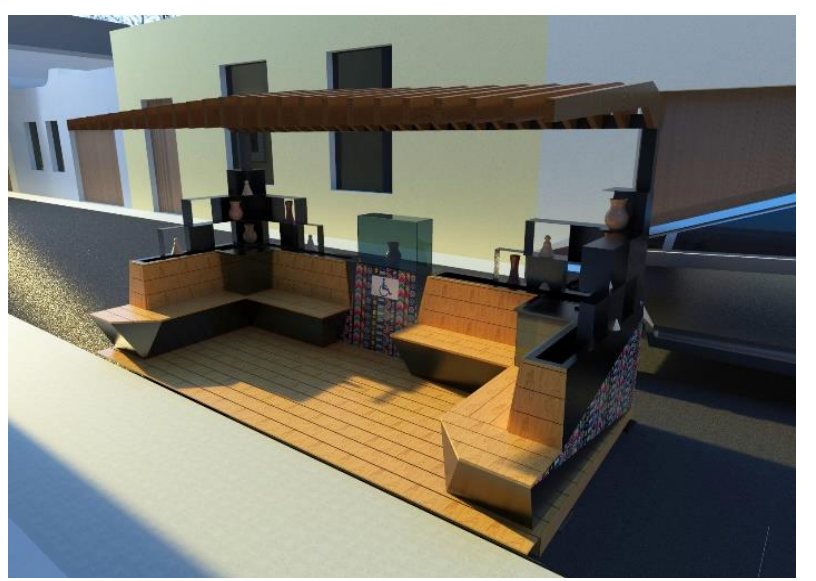

Graphic 6 Render, Parklet CEDAI

Finally, a render proposal made in keyshot 9 and modeled in SolidWorks 2020 was presented, where the elements of the parklet can be identified for their appreciation and approval. The final proposal was validated by presenting the model to a focus group of artisans in the CEDAI activity that concluded with the design stage of the parklet.

\section{Discussion}

The final design of this parklet was guided through the phenomenological approach used in this project, which helped to recognize the needs of the users and the objective of the project, also allowed to have a close contact with the artisans, know their environment, the context of CEDAI and its needs. The design was not made based on the aesthetics of the product or exclusive ideas of the designer, but rather as a social, complete and dynamic product.

Working together with the artisans of CEDAI was the most enriching process for this work, since they express their perception about what the culture and aesthetics of our country is in a very direct way, in addition to having extensive experience in working with materials and shapes. Likewise, the artisans know the context of the center in which they are located, information that could give meaning to the objectives and goals of this project.

Identifying the needs of this space, the users for whom it would be designed, and aligning it with the objective of "Querétaro se Diseña" required reflection on the results obtained in the empathizing stage, since decisions were made based on the knowledge of the context substantiate the requirements and needs to make an appropriate and strategic parklet design. 
The creative process, on the other hand, strengthened the project, since through ideas and proposals embodied in sketches as shown in graphic 3, elements that could contribute to the final proposal could be identified, taking into account the needs and desires previously identified.

It is important to note that after the validation of the design by government bodies, it is intended to build and evaluate the functionality, aesthetics and appropriation of the product by end users. To comply with the above, a statistical evaluation of the influx of people who come to CEDAI will be carried out to assess whether the parklet contributes to increasing visitors and economic income. For this, a survey based on an unstructured hedonic scale will be used to evaluate the perception of value of the users towards the space, the artisan products and the courses that may be offered. This survey will be analyzed with the method of Qualitative Comparative Analysis, whose main objective is to give an exhaustive explanation of the phenomenon that is being investigated from solutions based on Boleana's Algebra. This will allow describing the elements that intervene and their interaction by including an urban element in a public space such as the parklet.

\section{Acknowledgments}

Special thanks to the Autonomous University of Querétaro and CONACYT for their support in preparing this article.

\section{Conclusions}

Having the opportunity to make design that adds value to society is the most noble and important form of design that can be done. In this work that was carried out with the CEDAI community of artisans in the city of Querétaro, a value was obtained beyond the curriculum, since the design of an urban intervention that will have an important social impact in the city, something that reinforces our culture and that contributes to a vulnerable group such as artisans.

The methodology carried out was of great importance, since through social construction and phenomenology the idea of the design of this space was formed, together with the Design Thinking guide. It is considered that the methodology followed in this work was a great success, as it was perfectly adapted to the needs of the project and its context.

\section{References}

CEDAI Centro de Desarrollo Artesanal Indígena (S.F). Espacio dedicado a los ARTESANOS locales y nacionales. Brindando así, una amplia gama de arte para todos los gustos. Recuérda que contamos con un museo de muñecas artesanales y módulos de exposición artesanal. TRATO DIRECTO CON EL ARTESANO. [Información de pagina]. Facebook. https://www.facebook.com/museoartesanalindi gena/about

Design Thinking en Español. (2018, May 24). Design Thinking en Español. Recovered from: http://www.designthinking.es/inicio/

Ground Play (2020). San Francisco Parklet Manual. Retrieved February 17, 2020, from: https://groundplaysf.org/publication/sanfrancisco-parklet-manual/

Jaller, M., Rodier, C., Zhang, M., Lin, H., \& Lewis, K. (2021). Fighting for Curb Space: Parking, Ride-Hailing, Urban Freight Deliveries, and Other Users. National Center for Sustainable Transportation, 18-19. https://doi.org/10.7922/G22N50JJ

Lepe, A. (2018, 6 junio). El primer parklet en Guadalajara. Retrieved March 12, 2020, from: https://medium.com/@urbanistalepe/el-primerparklet-en-guadalajara-a683ad2fdb9e

Márquez, M., \& El Universal. (2019, noviembre 1). Nombra Unesco a la capital Ciudad Creativa de Diseño. Retrieved April 29, 2020, from: https://www.eluniversalqueretaro.mx/vidaq/nombra-unesco-la-capital-ciudad-creativa-dediseno

Martin, B., Hanington, B. M., \& Hanington, B. M. (2012). Universal Methods of Design. Macmillan Publishers.

Martínez, J. A., Espíritu, L., Arellano, R. E., \& Aguirre, J. J. (2018). PATRIMONIO LOCAL QUE SE DEBILITA: LOS ARTESANOS DE GÓMEZ FARÍAS, JALISCO (MÉXICO). Herencia, 31(1), 106-107 
Mura, M. (2013) Tactical Urbanism, Public Policy Reform, and 'Innovation Spotting' by Government: From Park(ing) Day to San Francisco's Parklet Program. [Tesis de maestria, Massachusetts Institute of Technology] Massachusetts Institute of Technology library.

NACTO. (2015, July 24). Parklets. Recovered from: https://nacto.org/publication/urban-streetdesign-guide/interim-design-strategies/parklets/

Novelo, V. (2002). SER INDIO, ARTISTA Y ARTESANO EN MÉXICO. Espiral Estudios Sobre Estado Y Sociedad (eISSN: 2594-021X), 9(25).

Recovered

from:https://www.redalyc.org/articulo.oa?id=13 802506

Querétaro se Diseña. (2020). Descubre Querétaro. Retrieved February 26, 2020, from: http://queretarosedisena.mx/es/ciudad-

creativa.php

Universidad de las Américas Puebla. (2014, February 12). Parklets, una alternativa para recuperar el espacio urbano. Recuperado 12 marzo, 2020 , de 